\title{
Helicobacter pylori chronic gastritis: correlation between endoscopic findings and histopathology with special reference to updated sydney system
}

\author{
Banik T. ${ }^{1}$, Kumar Bar P. ${ }^{2 *}$, Mandal S. ${ }^{3}$ \\ DOI: https://doi.org/10.17511/ijmrr.2020.i01.02
}

1 Tarak Banik, Assistant Professor, Malda Medical College, Malda, West Bengal, India.

2* Prasenjit Kumar Bar, Assistant Professor, Malda Medical College, Malda, West Bengal, India.

3 Saikat Mandal, Demonstrator, Malda Medical College, Malda, West Bengal, India.

\begin{abstract}
Aims of the study: Helicobacter pylori (H. pylori) induces inflammatory changes in the gastric mucosa variably correlated to different endoscopic and histologic features. The present prospective study aimed to correlate different endoscopic findings with histomorphological changes and the presence of $H$. pylori in the gastro-duodenal mucosa, in samples of dyspeptic patients. Methods: 60 dyspeptic patients of 18 years to 60 years of age were selected from outpatient department and screened with gastro-duodenoscopy and biopsy. The presence of $H$. pylori was determined by urease test on fresh biopsy specimens and histologically using the modified Giemsa stain. Findings were recorded and analyzed statistically. Results: Highest $(84.6 \%) H$. pylori positivity was seen in the 41-50 years age group. Majority of the patients had a normal upper gastro-intestinal endoscopy; among them majority (61.2\%) was positive for $H$. pylori infection. Most cases with endoscopic lesion in the gastro-duodenal mucosa were also positive for $H$. pylori infection. On biopsy, chronic gastritis was the most common (73.33\%) finding in 44 cases, among them, more than two-third (70.4\%) were positive for $H$. pylori. Conclusion: $H$. pylori gastritis is strongly associated with peptic ulcer diseases, chronic gastritis and non-ulcer dyspepsia. Endoscopy and biopsy play the main role in diagnosis and identification of the spectrum of involvement.
\end{abstract}

Keywords: H. Pylori, Endoscopy, Histopathology

Corresponding Author

Prasenjit Kumar Bar, Assistant Professor, Malda Medical College, Malda, West Bengal, India.

Email: pkbar41@gmail.com
How to Cite this Article

To Browse

Banik T, Bar PK, Mandal S. Helicobacter pylori chronic gastritis: correlation between endoscopic findings and histopathology with special reference to updated sydney system. Int J Med Res Rev. 2020;8(1):7-13.

Available From

https://ijmrr.medresearch.in/index.php/ijmrr/article/ view/1132

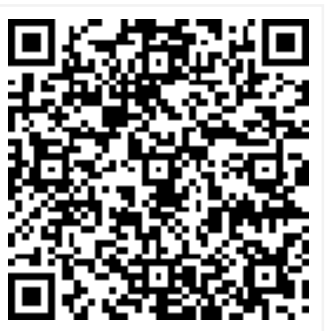

Manuscript Received 2019-1210

Conflict of Interest No
Review Round 1 2019-12-20

Funding $\mathrm{Nil}$

Review Round 2
2019-12-28
$\begin{gathered}\text { Ethical Approval } \\ \text { Yes }\end{gathered}$

Review Round 3

Plagiarism X-checker $9 \%$
Accepted 2020-01-03

Note 


\section{Introduction}

Helicobacter pylori are a gram negative, flagellated, spiral organism that resides in the antral mucosa, specifically in the interface between the surface gastric epithelial cells and the overlying mucous gel layer. It was first isolated from human gastric biopsy material in 1982 by Warren and Marshall in Australia [1]. It is a gastric pathogen that chronically infects more than half of all people worldwide. Presently its role has been established in chronic antral gastritis, duodenal ulcer, chronic gastric ulcer, dyspepsia, gastric carcinoma and gastric lymphoma. The International Agency for Research on Cancer of the WHO recommends that Helicobacter pylori be classified as a group I carcinogen [2,3]. In developing countries faeco-oral transmission is predominant [4]. Colonization by the bacterium is characterized by acute inflammatory reaction with infiltration of the lamina propria by mononuclear (and frequently polymorphonuclear) cells. Infection is self-limiting in few individuals, but the majority develops a chronic, active gastritis or antral type-B gastritis of varying severity [5]. H. pylori infection is found in more than $90 \%$ of duodenal ulcer patients and in around $75 \%$ of all peptic ulcer sufferers. Several studies have concluded that, eradication of H. pylori in ulcer patients leads to an eight-fold reduction in the rate of recurrence found with conventional anti-ulcer therapies $[6,7]$. The risk of gastric cancer has been estimated to be six-fold higher in $H$. pylori infected populations than in uninfected populations [8]. The diagnosis of $H$. pylori infection is currently based upon endoscopic biopsy-based tests- rapid urease test, histopathology and non-invasive tests like- urea breath test, stool antigen test, ELISA and PCR [9]. The advantage of histology is that, along with visualization of the organism, the spectrum of pathological changes associated with $H$. pylori likechronic gastritis, ulceration, erosion, atrophy, metaplasia or malignant change can also be assessed [4].

\section{Objectives}

To find out the spectrum of histological changes and endoscopic findings that occurs in the gastroduodenal mucosa in dyspeptic patients and its correlation with $\mathrm{H}$. pylori infection.

\section{Materials and Methods}

Study Type: Cross-sectional, hospital based
Observational study.

Study Design: Prospective cohort study.

Study setting/area, Population and Period: The study was conducted in the Department of Pathology, Malda Medical College, Malda, West Bengal, from May 2014 to September 2015.

\section{Sampling}

Selection of cohort: Endoscopic biopsy specimens and serum samples were collected from dyspeptic patients attending the gastroenterology clinic and undergoing endoscopy, in our institute and other hospitals, in and around Malda. 60 patients were enrolled in the study after an informed consent to undergo the required diagnostic evaluation of the samples. Ethics Committee approval was taken.

Sampling technique: Consecutive nonprobability technique used, consensus sampling.

\section{Inclusion criteria:}

1) Dyspeptic patients in the age group of 18 years to 60 years.

2) Patient who had given informed consent for the study.

\section{Exclusion criteria:}

(1) Patients who has taken anti-H. pylori antibiotics within 1 month.

(2) Proton pump inhibitors (PPI) within 2 weeks or $\mathrm{H} 2$ receptor blocker drugs within 1 week prior to endoscopy. (3) Patients with ischemic heart disease, chronic lung disease, diabetes mellitus and on long standing NSAID therapy.

(4) Pregnant or lactating females.

(5) Patients with known malignancy.

Study technique: Following a detailed clinical history, upper GI endoscopy was done. Findings at endoscopy were noted. Endoscopic biopsy was collected and subjected to urease test and histopathology. Serum samples were collected and stored at - 200C for IgG ELISA. Results were analysed using SPSS 16 for windows.

Techniques in details: Detailed history and clinical examination of patients were done; cases selected maintaining the inclusion and exclusion criteria. Venous blood collected for Anti H. pylori IgG ELISA. and brought to the laboratory for testing, keeping in an ice-lined chamber. Anti $\mathrm{H}$. pylori IgG ELISA kit 
Used; IBL, Hamburg Helicobacter pylori IgG ELISA for the in-vitro diagnostic qualitative and quantitative determination of IgG antibodies against Helicobacter pylori. Endoscopic biopsy was taken from the following parts of the stomach:4 quadrant antral biopsy containing 4 tissue bits, from corpus1 tissue bit, from fundus- 1 tissue bit and from areas with endoscopic evidence of gastritis, mucosal oedema, congestion or any other pathology, if found.

For biopsy urease test three endoscopic tissue bits were taken and immediately put in a vial containing freshly prepared urea solution for demonstration of urease activity and change of colour was observed. Positive cases showed change of colour from yellow to pink. A test tube containing urea solution was taken as control for colour change.

Three endoscopic tissue bits were collected in $10 \%$ buffered neutral formalin for histopathological examination and assessment of inflammation of the gastric mucosa by $\mathrm{H} \& \mathrm{E}$ stain. Modified Giemsa stain was used for demonstration of $H$. pylori in tissue sections. $H$. pylori was seen as spiral shaped bacteria, stained dark blue, seen in or near adherent mucus on the luminal side of the gastric surface and pit epithelial cells.

Data analysis: Statistical analysis of data was done by using SPSS, Version 16 software for Windows.

Statistical methods: Percentage, prevalence etc. were calculated using SPSS.

\section{Result and Analysis}

\section{Table-1: Age distribution and $H$. Pylori infection}

\begin{tabular}{|l|l|l|l|}
\hline $\begin{array}{c}\text { Age } \\
\text { group } \\
\text { in years }\end{array}$ & $\begin{array}{c}\text { Number of } \\
\text { dyspeptic } \\
\text { patients (\% of } \\
\text { Total) }\end{array}$ & $\begin{array}{c}\text { H. Pylori Positive } \\
\text { (\% of each group) } \\
\text { Total=41 }\end{array}$ & $\begin{array}{c}\text { H. Pylori Negative } \\
\text { (\% of each group) } \\
\text { Total=19 }\end{array}$ \\
\hline $18-20$ & $4(6.6)$ & $1(25.0)$ & $3(75.0)$ \\
\hline $21-30$ & $24(40.0)$ & $14(58.3)$ & $10(41.6)$ \\
\hline $31-40$ & $16(26.6)$ & $13(81.2)$ & $3(18.7)$ \\
\hline $41-50$ & $13(21.6)$ & $11(84.6)$ & $2(15.3)$ \\
\hline $51-60$ & $3(5.0)$ & $2(66.6)$ & $1(33.3)$ \\
\hline
\end{tabular}

Table 1 depicts that, dyspeptic symptoms were most common in the $21-30$ years age group (40\%); at the same time, $H$. pylori positivity was not so common in this age group (58.3\%).

Highest percentage of $H$. pylori positivity was seen in the $41-50$ years age group ( $84.6 \%$ ), followed by
41-50 years age group (81.2\%).

Table-2: Comparative evaluation of all the tests.

\begin{tabular}{|l|l|l|l|}
\hline \multicolumn{2}{|c|}{} & $\begin{array}{l}\text { Number of Cases } \\
(n=60)\end{array}$ \\
\hline IgG ELISA +ive $(n=35)$ & Urease +ive & Giemsa +ive & 27 \\
\cline { 3 - 4 } & & Giemsa -ive & 5 \\
\hline & Urease -ive & Giemsa +ive & 2 \\
\cline { 3 - 4 } & & Giemsa -ive & 1 \\
\hline IgG ELISA -ive $(n=25)$ & Urease +ive & Giemsa +ive & 3 \\
\cline { 3 - 4 } & & Giemsa -ive & 4 \\
\cline { 3 - 4 } & Urease -ive & Giemsa +ive & 0 \\
\cline { 3 - 4 } & & Giemsa -ive & 18 \\
\hline
\end{tabular}

Table 2 shows that, maximum numbers of dyspeptic patients (27 out of 60 cases) were positive for all three diagnostic tests. In 18 cases, all three tests were negative. Rest of the patients showed variable test results.

Table-3: Endoscopic features and association with H. Pylori

\begin{tabular}{|l|l|l|l|}
\hline $\begin{array}{l}\text { Endoscopic } \\
\text { features }\end{array}$ & $\begin{array}{c}\text { H. Pylori Positive } \\
\text { (\% of each group) } \\
\text { Total=41 }\end{array}$ & $\begin{array}{r}\text { H. Pylori Negative } \\
\text { (\% of each group) } \\
\text { Total=19 }\end{array}$ & $\begin{array}{l}\text { Number of } \\
\text { cases } \\
\text { Total=60 }\end{array}$ \\
\hline $\begin{array}{l}\text { 1. Normal } \\
\text { study }\end{array}$ & $19(61.2)$ & $12(38.7)$ & 31 \\
\hline $\begin{array}{l}\text { 2. Erosive } \\
\text { gastritis }\end{array}$ & $4(100)$ & $0(0.0)$ & 4 \\
\hline $\begin{array}{l}\text { 3. Non- } \\
\text { erosive } \\
\text { antral } \\
\text { gastritis }\end{array}$ & $9(100.0)$ & $0(0.0)$ & 9 \\
\hline $\begin{array}{l}\text { 4. Active } \\
\text { gastric ulcer }\end{array}$ & $2(66.6)$ & $1(33.3)$ & 3 \\
\hline $\begin{array}{l}\text { 5. Duodenal } \\
\text { ulceration }\end{array}$ & $4(100 \%)$ & $0(0.0 \%)$ & 4 \\
\hline $\begin{array}{l}\text { 6. Deformed } \\
\text { pylorus }\end{array}$ & $3(60.0 \%)$ & $2(40.0 \%)$ & 5 \\
\hline $\begin{array}{l}\text { 7. Neoplastic } \\
\text { ulcerated } \\
\text { lesion }\end{array}$ & $0(0.0 \%)$ & $2(100 \%)$ & 2 \\
\hline $\begin{array}{l}\text { 8. } \\
\text { Oesophagitis }\end{array}$ & $0(0.0 \%)$ & $2(100 \%)$ & 2 \\
\hline
\end{tabular}

Table 3 shows that, majority of the patients had a normal upper gastro-intestinal endoscopy; but among these cases, the majority (61.2\%) was positive for $H$. pylori infection.

Most of the cases which showed lesion in the gastro-duodenal mucosa at endoscopy were also positive for $H$. pylori infection. 2 out of the 60 dyspeptic cases, showed neoplastic ulcerated lesion 
In the stomach and were negative for $H$. pylori infection. Another 2 cases had oesophagitis at endoscopy and were also negative for infection.

Table-4: Histopathology and association with H. Pylori.

\begin{tabular}{|c|c|c|c|}
\hline $\begin{array}{c}\text { Histopatholo } \\
\text { gical } \\
\text { features }\end{array}$ & $\begin{array}{c}\text { H. Pylori Positive } \\
\text { ( } \% \text { of each group) } \\
\text { Total }=41\end{array}$ & $\begin{array}{c}\text { H. Pylori Negative } \\
\text { (\% of each group) } \\
\text { Total }=19\end{array}$ & $\begin{array}{l}\text { Number of } \\
\text { cases. } \\
\text { Total }=60\end{array}$ \\
\hline $\begin{array}{l}\text { 1. Normal } \\
\text { histology }\end{array}$ & $2(50.0)$ & $2(50.0)$ & 4 \\
\hline $\begin{array}{l}\text { 2. Chronic } \\
\text { gastritis }\end{array}$ & $31(70.4)$ & $13(29.5)$ & $44(73.3)$ \\
\hline $\begin{array}{l}\text { 3. Active } \\
\text { gastric ulcer }\end{array}$ & $2(66.6)$ & $1(33.3)$ & 3 \\
\hline $\begin{array}{l}4 . \\
\text { Duodenitis/du } \\
\text { odenal } \\
\text { ulceration }\end{array}$ & $4(100.0)$ & $0(0.0)$ & 4 \\
\hline $\begin{array}{l}\text { 5. Intestinal } \\
\text { metaplasia }\end{array}$ & $1(100)$ & $0(0.0)$ & 1 \\
\hline $\begin{array}{l}6 . \\
\text { Adenocarcino } \\
\text { ma }\end{array}$ & $0(0.0)$ & $2(100)$ & 2 \\
\hline $\begin{array}{l}\text { 7. Atrophic } \\
\text { gastritis }\end{array}$ & $1(100)$ & $0(0.0)$ & 1 \\
\hline $\begin{array}{l}\text { 8. Barret's } \\
\text { oesophagus }\end{array}$ & $0(0.0)$ & $1(100)$ & 1 \\
\hline
\end{tabular}

Table 4 depicts that, most of the cases (44 cases) of dyspepsia showed features of chronic gastritis (Fig 1B); among these, more than two-third (70.4\%) were positive for $H$. pylori. 4 cases showed normal histopathological findings and $H$. pylori infection could be detected in 2 cases (50.0\%) (Fig. 1C).

Among 4 cases of duodenitis, all were positive for $H$. pylori. Lymphoid follicle formation with germinal center was seen in 2 cases of chronic gastritis (Fig. 1D). Active gastric ulcer was found in 3 cases (Fig. $2 \mathrm{~A})$; out of these 2 cases $(66.6 \%)$ were positive for infection. Intestinal metaplasia (Fig 2D) and atrophic gastritis (Fig. 2B) was found in 1 case each, both were positive for $\mathrm{H}$. pylori.

2 cases of dyspepsia came out to be well differentiated adenocarcinoma with areas of highgrade dysplasia and both of those cases were negative for the organism (Fig. 2C). 1 case was due to Barret's oesophagus, which was also negative for infection.

Table-4: Parameters of gastritis according to the updated Sydney system [10].

\begin{tabular}{|c|c|c|c|c|c|}
\hline & & & = ORP U : & & \\
\hline & inflammation & $\begin{array}{l}\text { Mild } \\
\text { inflammation }\end{array}$ & $\begin{array}{l}\text { Moderate } \\
\text { inflammat }\end{array}$ & on G2 & $\begin{array}{l}\text { Severe } \\
\text { inflammation }\end{array}$ \\
\hline $\begin{array}{l}\mathbf{A} \\
\mathbf{N}\end{array}$ & $\begin{array}{l}\text { No } \\
\text { inflammation } \\
\text { G0 }\end{array}$ & Grade 0 & Grade I & Grade II & Grade II \\
\hline $\begin{array}{l}\mathbf{T} \\
\mathbf{R} \\
\mathbf{U}\end{array}$ & $\begin{array}{l}\text { Mild } \\
\text { inflammation } \\
\text { G1 }\end{array}$ & Grade I & Grade II & Grade II & Grade III \\
\hline M & $\begin{array}{l}\text { Moderate } \\
\text { inflammation } \\
\text { G2 }\end{array}$ & Grade II & Grade II & Grade III & Grade IV \\
\hline & $\begin{array}{l}\text { Severe } \\
\text { inflammation } \\
\text { G3 }\end{array}$ & Grade III & Grade III & Grade IV & Grade IV \\
\hline
\end{tabular}

As per the updated Sydney system of chronic gastritis, 44 cases showed mononuclear inflammatory infiltrate (73.3\%). The intensity of infiltrate was variable; G 1 gastritis was found in 29 cases, G 2 gastritis in 11 cases and G 3 gastritis in 4 cases. 4 cases of dyspepsia showed normal histology ( $\mathrm{G} 0$ gastritis).

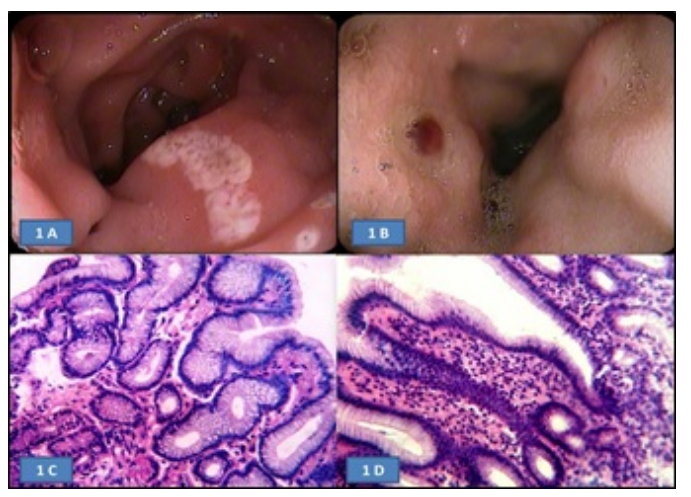

Fig. 1: (A). Gastric and duodenal erosion at endoscopy. (B). Active duodenal ulcer with red sign and deformed duodenal cap. (C). Normal histopathology of antral biopsy ( $\mathrm{G}$ 0). (D). Chronic gastritis with mild lymphomononuclear inflammatory infiltrate into the lamina propria (G 1) (H \& E x 400).

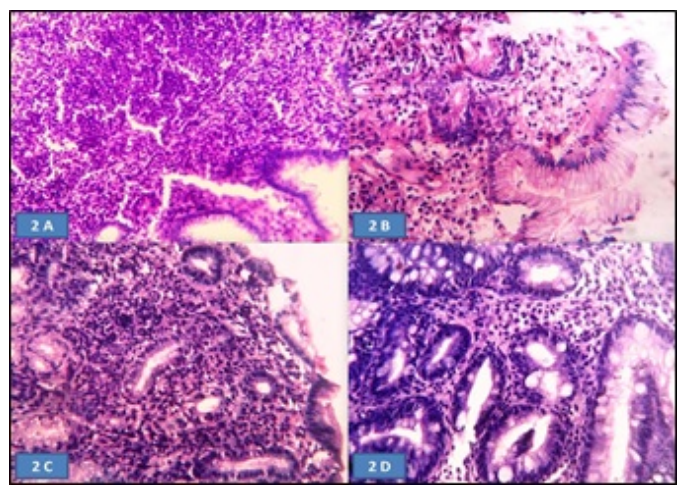


Fig-2: (A). Chronic gastritis with marked inflammation and lymphoid follicle formation in the lamina propria ( $G$ 3) ( $\mathrm{H} \& \mathrm{E} \times$ 400). (B). Active gastric ulcer. Lamina propria is oedematous containing mixed inflammatory infiltrates, predominantly polymorphs (H \& E X 400). (C). Atrophic gastritis ( $H \& E \times 400)$. (D). Intestinal metaplasia in a case of chronic gastritis ( $H \& E X$ 400).

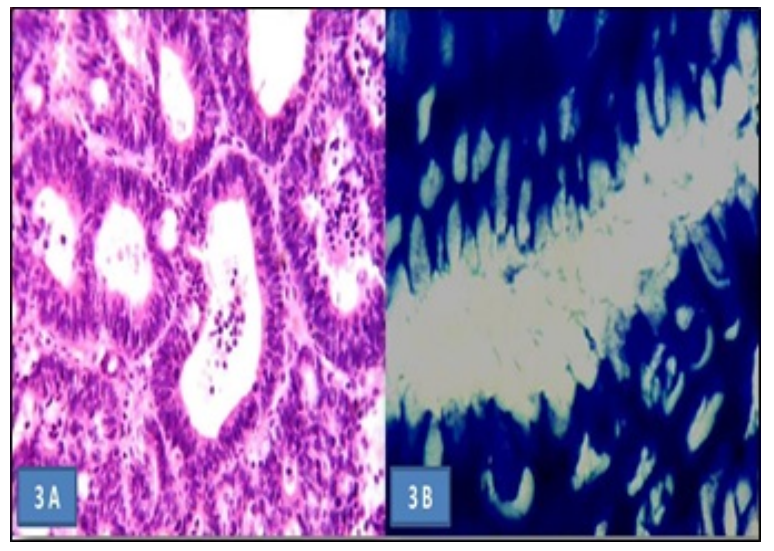

Fig-3: (A). Well differentiated adenocarcinoma (H \& E x 40). (B). H.pylori stained by modified giemsa stain ( $x$ 1000).

\section{Discussion}

In the present study, the age of the patients ranged from 19 years to 55 years, mean age being 33.4 years. Similar study done in India by Shrivastava UK et al. in 2004 showed mean age of occurrence of dyspepsia to be 35 years [11]. Dyspeptic symptoms were most common in the age group 21-30 years. Overall two-third cases fall in the $21-40$ years age range.

Similar studies done in India showed most cases of dyspepsia (34\%) in the 21-30 years age group [11]. Three diagnostic tests for the detection of $H$. pylori were performed- Anti $H$. pylori IgG ELISA, Biopsy urease test and Giemsa stain. The present study defined a patient to be positive for $H$. pylori infection, when the patient had symptoms of $H$. pylori disease and the biopsy urease test, and/or modified Giemsa stain was positive. This case definition was adopted in several other studies done in India or abroad [11-13].

At endoscopy, the patients had varied endoscopic findings. In this present study, more than half of dyspeptic patients $(51.6 \%)$ had normal UGI endoscopic study; but most of them were positive for infection (61.2\%). Excepting for oesophagitis
And neoplastic ulcerated lesion, majority of the patients who had organic lesion in the gastroduodenal mucosa at endoscopy, were also positive for $H$. pylori infection. On histopathological examination $73.3 \%$ cases (44 cases) were diagnosed as chronic superficial gastritis; among these, 31 cases $(70.4 \%)$ were positive and $(29.5 \%)$ were negative for $H$. pylori infection.

Normal histopathological findings were noted in 4 cases $(6.6 \%) ; 2$ cases $(50.0 \%)$ were positive and 2 (50.0\%) were negative for $H$. pylori. There were 4 cases $(6.6 \%)$ of duodenitis/duodenal ulceration; all were positive for infection. Among 3 cases (5.0\%) of benign gastric ulcer, all were positive for $H$. pylori. Well differentiated adenocarcinoma was diagnosed in 2 (3.3\%) cases on histopathology; none were positive for $H$. pylori. There was 1 case $(1.6 \%)$ each of atrophic gastritis and intestinal metaplasia; all of them were positive for infection.

Barret's oesophagus was diagnosed in 1 case $(1.6 \%)$, which was negative for $H$. pylori. In a similar study, Rajesh Kumar et al. showed chronic superficial gastritis as the most common histopathological finding in cases of dyspepsia [14]. Among the 45 cases of chronic superficial gastritis in the present study, 32 cases $(71.1 \%)$ were positive for $H$. pylori.

There were 4 cases of dyspepsia with normal histopathological findings, which were also normal on endoscopy; among these, 2 cases (50.0\%) were positive for $H$. pylori. Gastric mucosal biopsies from patients with $H$. pylori infection show a spectrum of changes and few studies have reported cases with normal or near normal histopathology associated with $H$. pylori infection $[15,16]$.

Several Indian studies have reported high degree of association of $H$. pylori with duodenal ulcer, chronic gastritis and non-ulcer dyspepsia. Dayal VM et al. and Prasad $\mathrm{S}$ et al. have reported $75-100 \%$ association of $H$. pylori with duodenitis/duodenal ulceration $[17,18]$.

Singh $\mathrm{V}$ et al reported $86.2 \%$ association with peptic ulcer in their study in Chandigarh [19]. In this way, the result of the present study is consistent with previous studies. Gastric carcinoma is a known complication of $H$. pylori infection, but any inference could not be drawn from the 2 cases of adenocarcinoma as the population was too small.

All the cases of chronic gastritis were graded according to the updated Sydney system. This 
System for grading and classifying chronic gastritis was devised to provide a standardized approach to the histologic interpretation of gastric biopsies in 1990 [20].

It was later updated in 1994 [21,22]. This system assesses the degree of inflammation on the following heading- (1) Chronic inflammation- scored as 0-none; 1-mild; 2-moderate; 3-marked. (2) Activity (neutrophil infiltration); (3) Atrophy; (4) Intestinal metaplasia; and (5) H. pylori density- all are graded as mild, moderate and severe.

There was no significant correlation between the degree of inflammation and heaviness of $H$. pylori infection in the present study. Tabei SZ et al. had also showed no significant correlation between these two in their study [23].

The limitation of the current study was the small sample size (60 patients). The study needs to be continued and results can be extrapolated among the population at large, once significant sample size is attained.

\section{Conclusion}

H. pylori most common in the 41-50 years age group. Early diagnosis of $H$. pylori by IgG ELISA, Modified Giemsa, and Urease test along with endoscopy followed by biopsy in dyspeptic patients may prevent $H$. pylori infection related complications. Helicobacter pylori infection is an etiopathogenetic cause of chronic gastritis in more than $73 \%$ of the cases.

\section{What the study adds to the existing knowledge}

Though the sample size was small, still the present study focused light on a topic where no similar study is available in this part of rural Bengal. Again, it emphasized the role of a uniform reporting format for endoscopic biopsy specimens in cases of inflammatory conditions.

\section{Author's contribution}

Dr. Tarak Banik: Concept designing and conducting the study \& writing the manuscript.

Dr. Prasenjit Kumar Bar and Dr. Saikat Mandal: Conducting the study, statistical analysis and preparing the manuscript suitable for publication.

\section{Reference}

01. Warren JR \& Marshall BJ. 1983, Unidentified curved bacillus on gastric epithelium in chronic active gastritis. Lancet. 1983;1(8336)1273-75. doi: [Article] [Crossref]

02. International Agency for Research on Cancer. Schistosomes, Liver flukes \& $\mathrm{H}$ pylori, IARC Monographs on the Evaluation of Carcinogenic Risks to Humans. 61, Lyon, France IARC. 1994. [Crossref]

03. Calam J. Clinician's guide to Helicobacter pylori. 1st ed (Chapman \& Hall, London). 1996;72-78. [Crossref]

04. Logan R P H, Walker MM. ABC of Upper Gastrointestinal Tract- Epidemiology \& Diagnosis of $\mathrm{H}$ pylori infection-Robert PH Logan \& Marjorie M Walker. BMJ. 2001;323(7318)920-922. doi: [Article] [Crossref]

05. Price AB. The Sydney system- histological division. J Gastroenterol Hepatol. 1991;6(3)209-22. doi: [Article] [Crossref]

06. Fiocca R, Solcia E, Santoro B. Duodenal ulcer relapse after eradication of Helicobacter pylori. The Lancet. 1991;337(8757)1614. doi: [Article] [Crossref]

07. Graham DY, Lew GM, Klein PD, Evans DG, Evans $D J$, Saeed ZA, et al. Effect of treatment of Helicobacter pylori infection on the long-term recurrence of gastric or duodenal ulcer- a randomized, controlled study. Ann Int Med. 1992; 116(9)705-708.

doi: [Article] [Crossref]

08. The Eurogast Study Group- 1993. An international association between Helicobacter pylori infection and gastric cancer. Lancet. 341(8847)1359-1362. doi: [Article] [Crossref]

09. Barthal JS, Everett ED. Diagnosis of Campylobacter pylori infections- The gold standard \& alterations. Rev Inf Dis. 1990;12(1)S107-S114. doi: [Article] [Crossref]

10. Hassan TM, Al-Najjar SI, Al-Zahrani IH, Alanazi FI, Alotibi MG. Helicobacter pylori chronic gastritis updated Sydney grading in relation to endoscopic findings and $\mathrm{H}$ pylori IgG antibodydiagnostic methods. J Micros Ultrastruct. 2016;4(4)167-174.

doi: [Article] [Crossref] 
11. UpendraK S, Aman G, Arun G, Arati B. Role of Helicobacter pylori in functional dyspepsia. Indian J Surg. 2004;66(6)341-346.

doi: [Article] [Crossref]

12. Destura RV, Labio ED, Barrett LJ, Alcantara CS, Gloria VI, Daez ML, et al. Laboratory diagnosis and susceptibility profile of Helicobacter pylori infection in the Philippines. Ann Clinic Microbiol Antimicrob. 2004;3(1)25. doi: [Article] [Crossref]

13. C Vu, YY Ng. Prevalence of Helicobacter pylori in Peptic Ulcer Disease in a Singapore Hospital. Singapore Med J. 2000;41(10)478-481. [Crossref]

14. Kumar R, Bano G, Kapoor B, Sharma S, Gupta Y. Clinical Profile in $\mathrm{H}$ Pylori Positive Patients in Jammu. JK Sci. 2006;8(3)148-150. [Crossref]

15. Stolte M, Edis S. Lymphoid follicles in antral mucosa- Immune response to Campylobacter pylori. J Clin Pathol. 1989;42(12)1269-1271. doi: [Article] [Crossref]

16. Tytgat GMJ, Rows EJ. Helicobacter pylori in duodenal and gastric ulcer disease. Bailliere's Clin Gastroenterol. 1995;9(3)529-545. doi: [Article] [Crossref]

17. Dayal VM, Kumar P, Kamal J, Shahi SK, Agarwal $B R$. Triple drug therapy of $\mathrm{H}$ pylori infection in duodenal ulcer disease Indian. J Gastroenterol. 1997; 16(2)46-48.

[Crossref]
18. Prasad S, Mathew M, Chandy G, Prasanna Rajan D, Venkateswaran S, Ramakrishna BS. Prevalence of Helicobacter pylori in Southern Indian controls and patients in Gastroduodenal disease. J Gastroenterol Hepatol. 1994;9(5)501506.

doi: [Article] [Crossref]

19. Singh V, Trikha B, Nain CK, Singh K, Vaiphei K. Epidemiology of Helicobacter pylori and peptic ulcer in India. J Gastroenterol Hepatol. 2002;17(6)659-665.

doi: [Article] [Crossref]

20. Misiewicz J], Tytgat GN J, Goodwin C\&S. The Sydney system- a new classification of gastritis. J Hepatol Gastroenterol. 1991;6(3)209-222. doi: [Article] [Crossref]

21. Genta RM, Dixon MF. The Sydney system revisited the Houston international gastritis workshop. Am J Gastroenterol. 1995;90(7)1039-1041.

22 [Crossref]

22. Genta RM. Helicobacter pylori, inflammation, mucosal damage, and apoptosis pathogenesis and definition of gastric atrophy. Gastroenterol. 1997;113(6)551-555.

doi: [Article] [Crossref]

23. Tabei SZ, Mojalal M, Kumar PV. Chronic gastritis associated with Helicobacter pylori infection- a histopathologic study of 200 cases. Med J Iran Hosp. 1998; 1(1)11-20.

[Crossref] 